\title{
RELATIONSHIP BETWEEN INSTABILITY INDICES AND EXTREME RAINFALL IN THE STATE OF RIO GRANDE DO SUL, BRAZIL
}

\author{
Vanúcia Schumacher ${ }^{1}$ and Mateus da Silva Teixeira²
}

\begin{abstract}
The relationship between instability indices and extreme daily rainfall over state of Rio Grande do Sul, Brazil, is studied, as well as the main differences between extreme and ordinary rainfall events. A total of 105 extreme and 342 ordinary rainfall events were identified in 2000-2009 period. Composites of atmospheric fields for up to two days prior to the events showed some important features that may be considered precursors for extreme rainfall in this region: a surface low-pressure center over Paraguay and northern Argentina, a more intense northerly flow in this region and, consequently, a large moisture flux convergence over southern Brazil, specially over state of Rio Grande do Sul. Correlations between instability indices and extreme rainfall showed statistically significant liner relationships for almost all instability indices. However, the small degree of correlations does not support any quantitative rainfall forecasting methodology based only on instability indices.
\end{abstract}

Keywords: rainfall forecasting, atmospheric instability, composites, correlation.

RESUMO. A relação entre os índices de instabilidade e a chuva extrema sobre o estado do Rio Grande do Sul, Brasil, é estudada neste trabalho, bem como as principais diferenças entre eventos comuns e extremos de chuva diária. Um total de 105 eventos extremos e 342 comuns foram identificados dentro do período de 2000 a 2009. Compostos de campos atmosféricos para até dois dias anteriores aos eventos mostraram características importantes que podem ser consideradas precursoras à chuva extrema nesta região: um centro de baixa pressão em superfície sobre o Paraguai e o nordeste da Argentina, um escoamento de norte mais intenso nesta região e, consequentemente, maior convergência do fluxo de umidade sobre o sul do Brasil, especialmente sobre o estado do Rio Grande do Sul. As correlações entre os índices de instabilidade e a chuva extrema mostraram relações lineares estatisticamente significativas para quase todos os índices. Entretanto, o pequeno grau das correlações não suporta qualquer metodologia de previsão quantitativa de chuva baseada somente em índices de instabilidade.

Palavras-chave: previsão de chuva, instabilidade atmostérica, compostos, correlação.

\footnotetext{
1 Universidade Federal de Viçosa - UFV, Pós-Graduação em Meteorologia Aplicada, Departamento de Engenharia Agrícola, Avenida Peter Henry Rolfs, s/n, 36570-900 Viçosa, MG, Brazil. Phone: +55(31) 3899-1890; Fax: +55(31) 3899-2735 - E-mail: vanucia-schumacher@hotmail.com

2Universidade Federal de Pelotas - UFPel, Centro de Pesquisas e Previsões Meteorológicas, Faculdade de Meteorologia, Av. IIdefonso Simões Lopes, 2751, Bairro Arco Íris, 96060-290 Pelotas, RS, Brazil. Phone: +55(53) 3277-6690; Fax: +55(53) 3277-6722 - E-mail: mateus.teixeira@ufpel.edu.br
} 


\section{INTRODUCTION}

Extreme rainfall events in southern South America bring large social, economic and environmental impacts especially in urban areas. Floods are the main consequences of these events. The occurrence of rainfall extremes in this region is controlled by several atmospheric systems of different time and space scales (Cavalcanti, 2012; Reboita et al., 2012). The rainfall regime in southern Brazil is well-behaved through the year with cold fronts and extratropical cyclones as the main responsible for observed rainfall (Rao \& Hada, 1990; Grimm, 2009).

Also, it is observed over southern South America Mesoscale Convective Systems (MCS) which often develop over La Plata River basin. Most part of these MCS form over northeast Argentina and Paraguay, later moving eastward-southeastward. Andes Cordillera has a crucial role in their formation and maintenance since deflection of trade winds southward help to transport huge amount of water vapor and warm air from Amazon basin. The interaction of this low-tropospheric flow - known as Low-Level Jet (LLJ) - with intense upper-tropospheric flow - known as Jet Stream - with an intense upper-tropospheric flow - known as Jet Stream - is an important mechanism for convection (Velasco \& Fritsch, 1987; Zipser et al., 2006; Salio et al., 2007; Marengo et al., 2009; Rasmussen et al., 2014; Rasmussen \& Houze, 2016).

Planetary scale forcing can also modulate frequency and intensity of rainfall in southern Brazil. The El Niño-Southern Oscillation (ENSO) phenomenon is the major example being associated with highest frequency of extreme rainfall events (also in several other parts of world) during its warm phase (El Niño) (Tedeschi et al., 2014).

Therefore, the forecasting and monitoring of extreme rainfall events are very important for human activities nowadays. Wellissued warnings for these events can help to avoid or mitigate the damages caused by them. Extreme rainfall events are associated with highly unstable environments and one of the most used tools to forecasting the potential for convection and thus for rainfall is instability indices. However, little is known about real relationship between rainfall and instability indices.

The main issue of this study is to evaluate such relationship for extreme rainfall events occurred in state of Rio Grande do Sul (RS), southern Brazil, in the 2000-2009 period. Mean synoptic atmospheric conditions are also presented to provide forecasters and meteorology researchers large-scale configurations associated with these events.

\section{METHODOLOGY}

\section{Extreme and Median Events}

In order to compare how different is an extreme rainfall event from an ordinary one, monthly mean 50 and 95 percentiles were computed from daily rainfall data for 2000-2009 period for 23 weather stations distributed over RS (Fig. 1). Data are available from Banco de Dados Meteorológicos para Ensino e Pesquisa from Instituto Nacional de Meteorologia (BDMEP-INMET).

An extreme rainfall event was selected when daily rainfall was equal or greater than monthly mean 95 percentile. Dates in which only one weather station reported such amount of rainfall are not considered, as long as it can be result from local weather conditions and not from a synoptic weather configuration. A daily rainfall event was classified as ordinary when observed rainfall was inside an interval of $\pm 10 \%$ about monthly mean 50 percentile in more than one weather station. For both classes of events, only non-consecutive events were considered and previous day must have no important rainfall (lower than $0.5 \mathrm{~mm}$ ).

\section{Composites Fields and Instability Indices}

Synoptic characteristics associated with extreme rainfall events identified over RS are showed by composite fields of the following atmospheric variables: mean sea level pressure, geopotential height and relative vorticity at $500 \mathrm{hPa}$, wind divergence at $200 \mathrm{hPa}$, moisture flux divergence and thermal advection at $850 \mathrm{~h}$ $\mathrm{hPa}$. Data for composites were obtained from Climate Forecast System Reanalysis (CFSR), from National Centers for Environmental Prediction (NCEP) (Saha et al., 2010). Composites for each season of the year were obtained for up to two days prior to start of rainfall observation in the events, being 12 UTC of selected dates considered D0, D-1 24 hours prior D0, and D-2 48 hours prior D0. Statistical significance of composites was estimated with the non-parametric Wilcoxon-Mann-Whitney statistical test (Wilks, 2006) in a 95\% level of significance, using ordinary rainfall events to look significant differences between these classes of events.

Seasonal composites of instability indices were also calculated. Indices as Convective Available Potential Energy (CAPE), Convective Inhibition (CIN) and Lifted Index (LI) were obtained directly from CFSR data, while $K$ and Total Totals (TT) indices were calculated as Henry (1987) and Nascimento (2005). CFSR data provides CAPE for four different starting points: from the ground (CAPE_ground), and from 255, 180, and $90 \mathrm{hPa}$ above ground level (CAPE_255, CAPE_180, and CAPE_90). LI index has also information for different level references: from the ground (LI) and from most unstable level between 9 and $1600 \mathrm{~m}$, known as Best Lifted Index (BLI). Table 1 presents thresholds for strong instability to each index.

\section{Instability Indices versus Extreme Rainfall}

Even knowing instability indices are frequently used by forecasters to identify conditions for severe weather and heavy rainfall, 


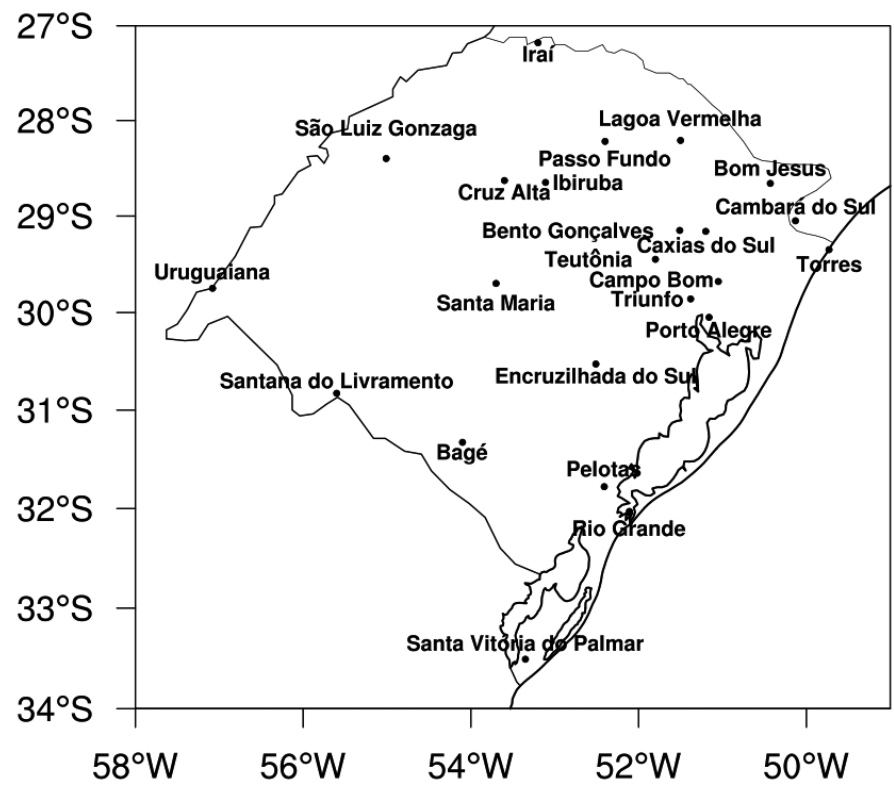

Figure 1 - Geographic distribution of the 23 weather stations over RS.

Table 1 - Thresholds for each instability indices indicating atmospheric instability.

\begin{tabular}{|c|c|c|}
\hline Index & Skill scores & References \\
\hline CAPE & $\geq 1000 \mathrm{~J} \mathrm{~kg}^{-1}$ & Bluestein (1993) \\
CIN & $0-50 \mathrm{~J} / \mathrm{kg}^{-1}$ & Houze (2014) \\
LI and BLI & $\geq-4 \mathrm{~K} \mathrm{or}^{\circ} \mathrm{C}$ & Houze (2014) \\
$\mathrm{K}$ & $\geq 30^{\circ} \mathrm{C}$ & Henry (1987) \\
TT & $\geq 40^{\circ} \mathrm{C}$ & Nascimento (2005) \\
\hline
\end{tabular}

some questions still arise: how good is instability indices to forecast rainfall, specially, extreme rainfall? What is the relationship between them? To trying assess such relationship seasonal correlations were calculated between each instability index and rainfall observed in the events selected.

Instability indices values from CFSR data were interpolated to weather stations coordinates, allowing Spearman Correlation Coefficient being computed for indices and rainfall for each location on RS. Statistical significance of Spearman correlations was tested at 95\% confidence level, using Fisher transformation. Correlation coefficients should be greater or equal to the seasonal critical values presented in Table 2 for being considered statistically significant.

Table 2 - Critical correlation values for each season.

\begin{tabular}{|c|c|c|}
\hline Seasons & $n$ & r_critical \\
\hline JFM & 31 & 0.301 \\
AMJ & 19 & 0.391 \\
JAS & 21 & 0.370 \\
OND & 34 & 0.287 \\
\hline
\end{tabular}

\section{RESULTS}

\section{Annual and Monthly Distributions of Extreme and Median Rainfall}

Monthly mean percentiles of extreme rainfall events are show in Figure 2. It can be seen high extremes in October and November, higher than $70 \mathrm{~mm}$. In later summer and earlier autumn events with 95 percentile values above $70 \mathrm{~mm}$ (outliers) are observed. On average, June is the only month with median less than $40 \mathrm{~mm}$, showing that the majority of events has extreme rainfall above $40 \mathrm{~mm}$

A total of 105 events were identified as extreme and 342 as ordinary events in 2000-2009 period. Figure 3 shows the annual and monthly variation for these events. It is not possible to observe important trends in the frequency of extreme and median events in the studied period. There is, on the other hand, a minimum of events in 2001 for both groups of events. It could be associated with La Niña observed in 2000 and 2001. In the monthly distribution, there is no evidence for preference of occurrence of 


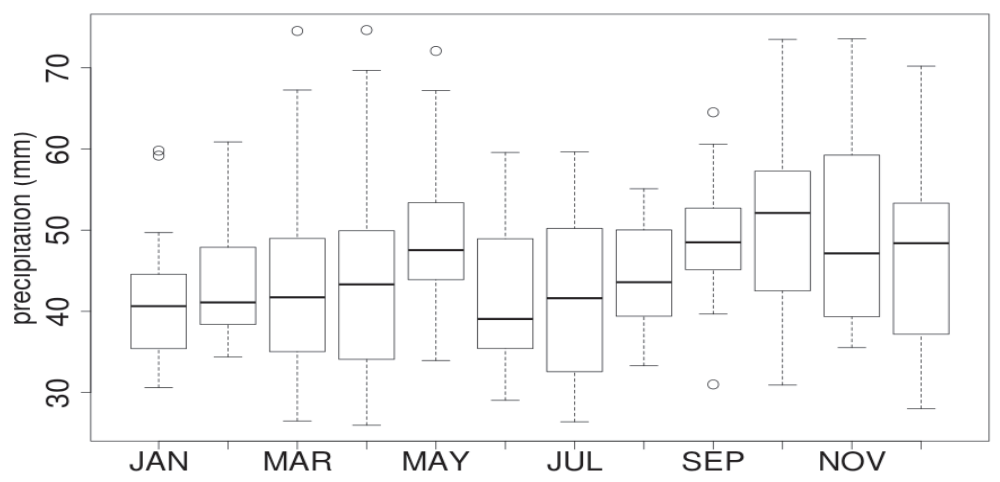

Figure 2 - Monthly distribution mean 95 percentiles in extreme rainfall episodes for period 2000-2009. Circles indicate discrepant values.
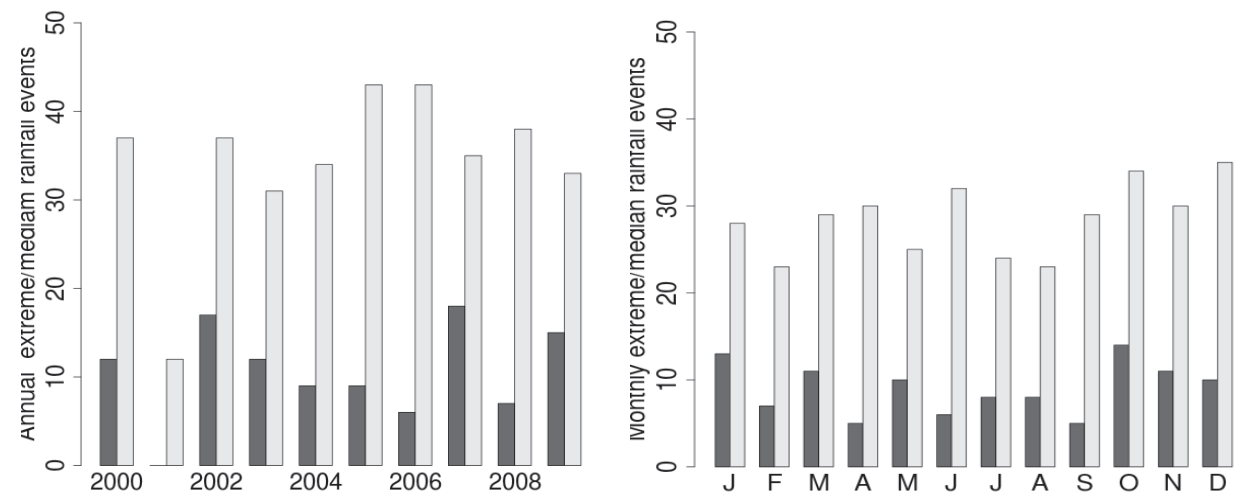

Figure 3 - Annual (a) and monthly (b) distribution of the extreme rainfall (dark) and median (gray) events over RS, southern Brazil, from 2000-2009.

extreme and median events in any month. January and October have higher frequency of events.

\section{Mean Characteristics Associates with Extreme Rainfall Events}

This section presents seasonal composites fields for extreme rainfall events identified in 2000-2009 period. Sequences of composites are useful for tracking the evolution of the synopticscale systems responsible for extreme rainfall. Composites for autumn are presented in detail, since they showed remarkable differences in relation to median events. For other seasons, only noticeable differences from autumn events are presented.

Autumn: Composites fields for 500-hPa geopotential height are shown in Figure 4a. It could be observed a decrease of spatial coverage of significant differences between extreme and median events from D-1 (not shown) to D0. However, there is an extensive area of significant differences in sea level pressure west of RS for D0 (Fig. 4b), where a low-pressure center is present. This low-pressure center contributes to an increase of pressure gradient over northeast Argentina and southern Brazil, which in turn establish an intense northerly flow. This northerly flow is commonly associated with transport of warm and moist air from Amazon basin to northern Argentina and southern Brazil.

Figure 5 shows the result of the increase of pressure gradient west of RS. Northerly flow covers great part of Brazil with significant differences to median events located over almost entire southern Brazil. These intense northerly winds speeds (greater than $18 \mathrm{~ms}^{-1}$ over Paraguay, Bolivia, and state of Mato Grosso do Sul, Brazil), as already mentioned, bring moisture from Amazon basin which converge over RS.

Composites fields for 200-hPa wind divergence, $850-\mathrm{hPa}$ temperature advection and $500-\mathrm{hPa}$ relative vorticity advection (not shown) did not present any significant differences between extreme and median events. It appears these parameters are not good precursors to the occurrence of extreme rainfall. When instability indices were analyzed, only $\mathrm{K}$ and $\mathrm{TT}$ presented significant differences. Although composites shown in Figure 6 present values indicative of atmospheric instability (see Table 1) over almost entire domain, the differences between extreme and ordinary 

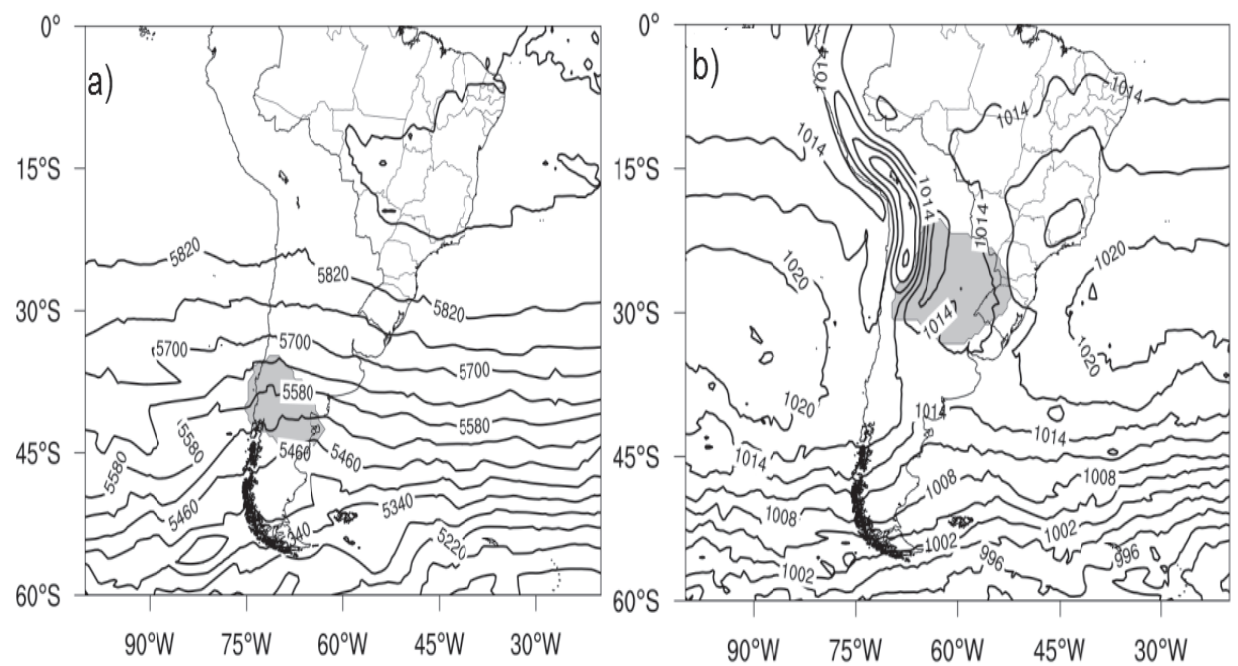

Figure 4 - 500-hPa geopotential height (mgp) composite (a) and SLP (hPa) (b) referring to D0 for autumn. Shaded areas are significant at $95 \%$ level.
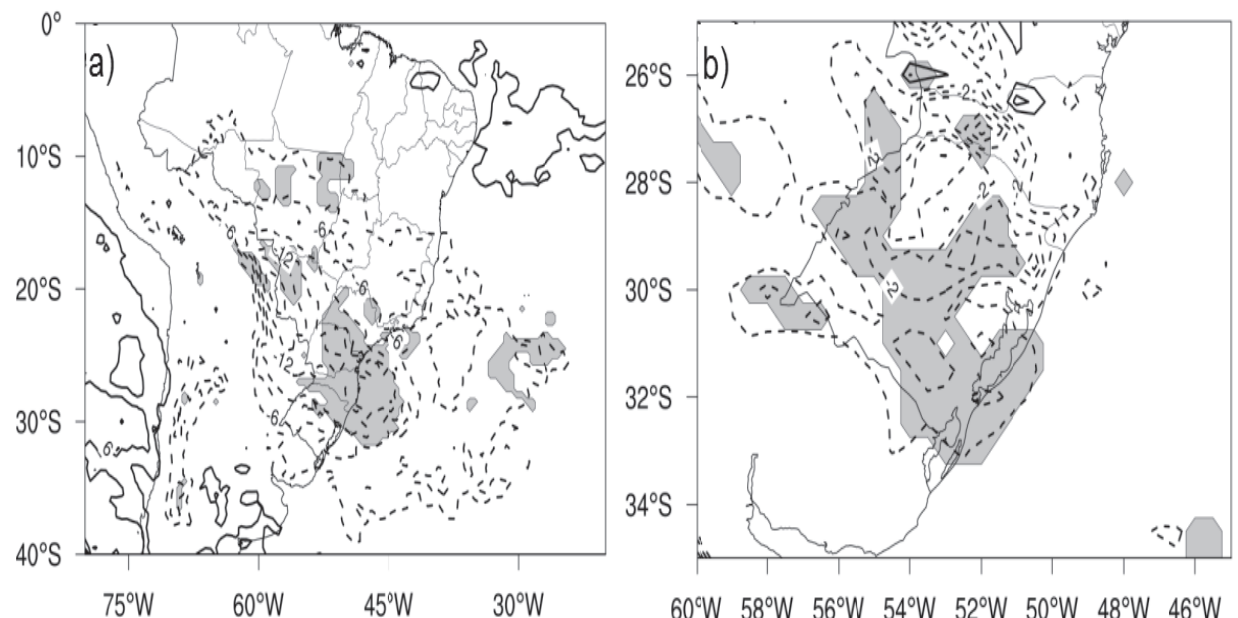

$60^{\circ} \mathrm{W} \quad 58^{\circ} \mathrm{W} \quad 56^{\circ} \mathrm{W} 54^{\circ} \mathrm{W} 52^{\circ} \mathrm{W} \quad 50^{\circ} \mathrm{W} \quad 48^{\circ} \mathrm{W} \quad 46^{\circ} \mathrm{W}$

Figure 5 - As Figure 4, but for meridional wind $(\mathrm{m} / \mathrm{s})$ at $850 \mathrm{hPa}(\mathrm{a})$ and moisture flux divergence $\left(10^{-7} \mathrm{~s}^{-1}\right)$ (b) referring to $\mathrm{D} 0$.

events are small over RS. Instability indices also do not seem to be good precursors for extreme rainfall.

\section{Intraseasonal Differences}

Winter: Magnitude of significant differences between extreme and ordinary events for $500-\mathrm{hPa}$ geopotential height are similar to autumn season. However, a more pronounced trough east of Andes is observed (Fig. 7a). Strong pressure gradient, especially on RS is also observed, but it seems to be a common feature for both extreme and ordinary events (Fig. 7a). It is interesting to note that northerly flow speeds increase from D-1 to D0 over boundary between Brazil, Bolivia and Paraguay. Again, as seen in mean sea level pressure, this northerly flow does exist in both set of events
(Fig. 8). Indices K and TT (not shown) have presented typical values for storms, but there were not significant differences between extreme and ordinary events.

CAPE (independent of starting level; see Methodology) does not indicate high potential for convection, since maximum value was about $650 \mathrm{~J} / \mathrm{kg}^{-1}$ over Argentina, Uruguay and RS. However, one should remember that composites have an inclination to smooth the results. Also, these fields are related to 12 UTC, or 09 local time. High potential to convection, what means high values of CAPE (see Table 1), is often seen during afternoon, but not in the morning. Nevertheless, it can be assumed that there is a small potential to convection, since significant differences areas were observed, showing that extreme rainfall events are somewhat distinct from ordinary ones (Fig. 9a). CAPE and CIN were also 


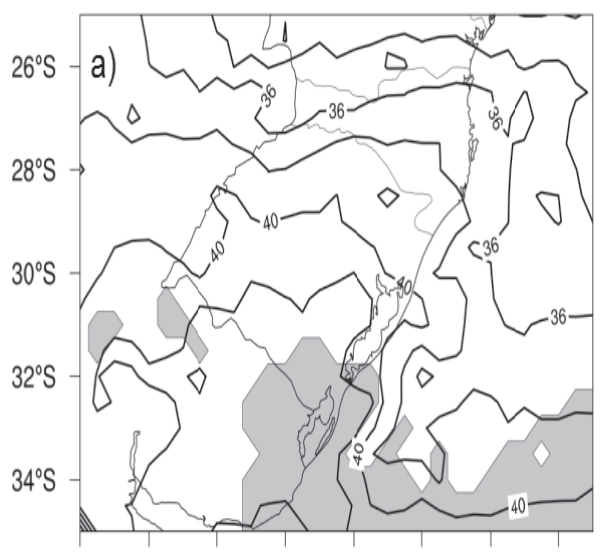

$60^{\circ} \mathrm{W} 58^{\circ} \mathrm{W} 56^{\circ} \mathrm{W} 54^{\circ} \mathrm{W} 52^{\circ} \mathrm{W} 50^{\circ} \mathrm{W} \quad 48^{\circ} \mathrm{W} \quad 46^{\circ} \mathrm{W}$

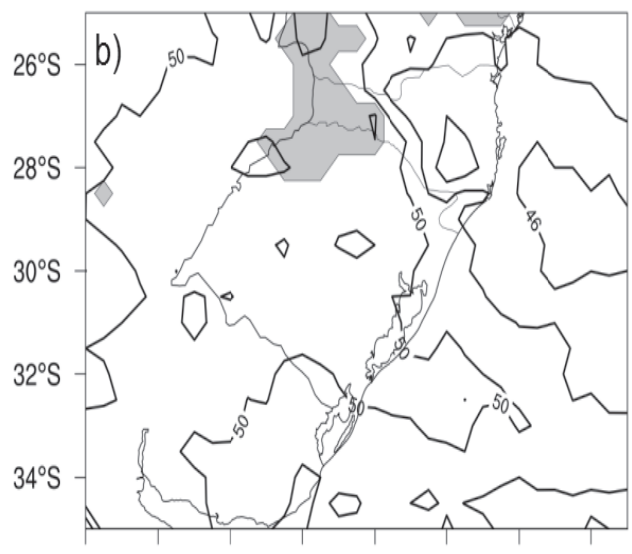

$60^{\circ} \mathrm{W} 58^{\circ} \mathrm{W} 56^{\circ} \mathrm{W} 54^{\circ} \mathrm{W} 52^{\circ} \mathrm{W} 50^{\circ} \mathrm{W} \quad 48^{\circ} \mathrm{W} 46^{\circ} \mathrm{W}$

Figure 6 - As Figure 4 , but for $\mathrm{K}(\mathrm{a})$ and $\mathrm{TT}(\mathrm{b})\left({ }^{\circ} \mathrm{C}\right)$, referring to $\mathrm{DO}$
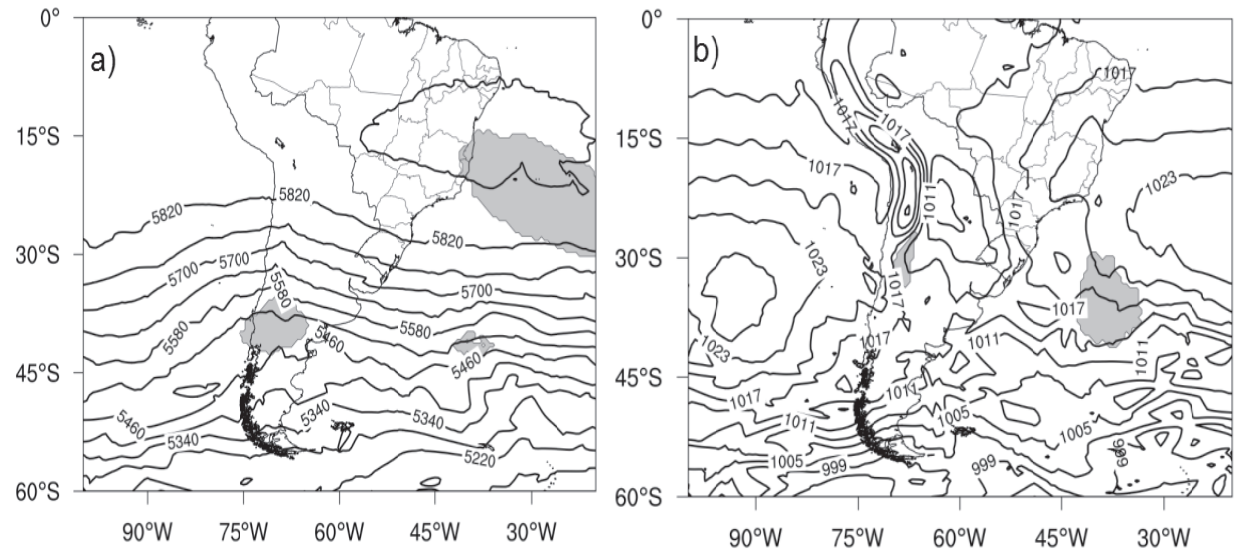

Figure 7 - As Figure 4, but to 500-hPa geopotential height (mgp) (a) and SLP (hPa) (b) referring to D0 for winter.
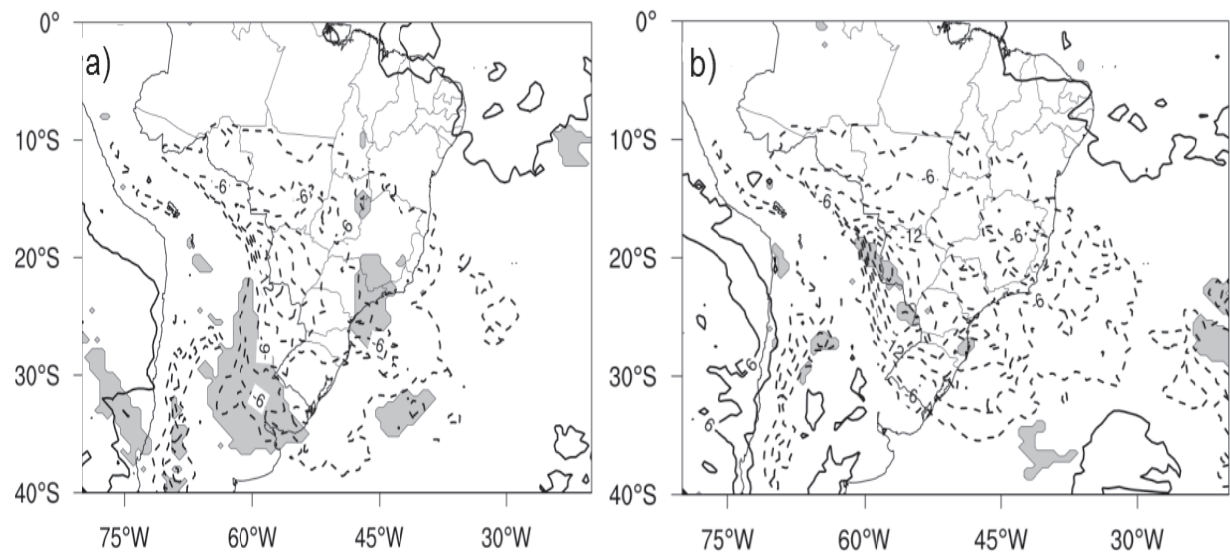

Figure 8 - As Figure 4, but to meridional wind (m/s) at $850 \mathrm{hPa}$, referring to D-1 (a) and D0 (b), respectively, for winter. 


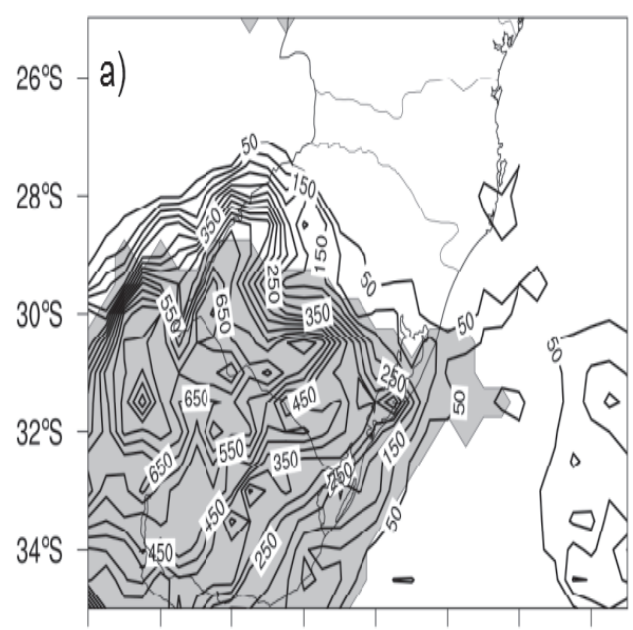

$60^{\circ} \mathrm{W} 58^{\circ} \mathrm{W} \quad 56^{\circ} \mathrm{W} \quad 54^{\circ} \mathrm{W} \quad 52^{\circ} \mathrm{W} \quad 50^{\circ} \mathrm{W} \quad 48^{\circ} \mathrm{W} \quad 46^{\circ} \mathrm{W}$

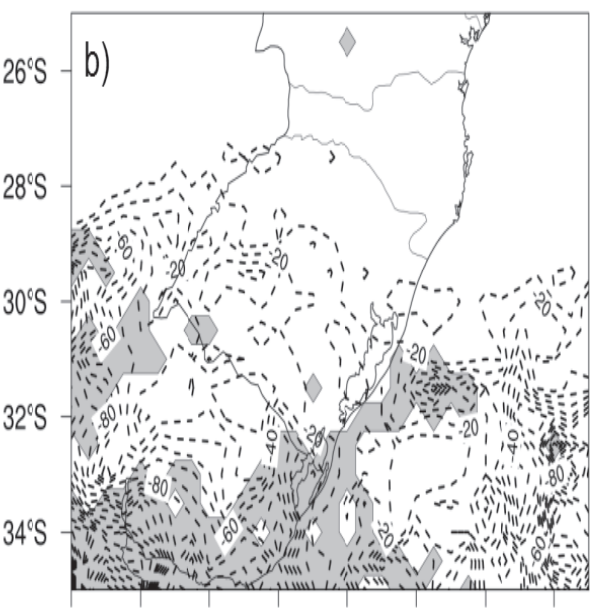

$60^{\circ} \mathrm{W} 58^{\circ} \mathrm{W} 56^{\circ} \mathrm{W} 54^{\circ} \mathrm{W} 52^{\circ} \mathrm{W} 50^{\circ} \mathrm{W} 48^{\circ} \mathrm{W} 46^{\circ} \mathrm{W}$

Figure 9 - As Figure 4, but to CAPE_255 (a) and CIN_255 (b) (J/kg) referring to D0 for winter.

observed over some areas near RS (Fig. 9b). According to Nascimento (2005), presence of CIN in unstable environments can increase the chance of occurrence of deep convection due formation of a few convective cells, reducing competition for CAPE and increase the duration of convection.

Spring: 500-hPa geopotential height differences for autumn are the largest among all seasons. Although there is not a pronounced trough at middle levels of troposphere, the differences between extreme and ordinary events are spatially extensive and have a small increase between D-1 and D0 (Fig. 10). This configuration provides a stronger pressure gradient (in relation to ordinary events) observed since two days prior extreme rainfall (Fig. 11). With a stronger gradient pressure, stronger northerly flow is observed over a large area of southern South America, bringing moisture to RS (Fig. 12).
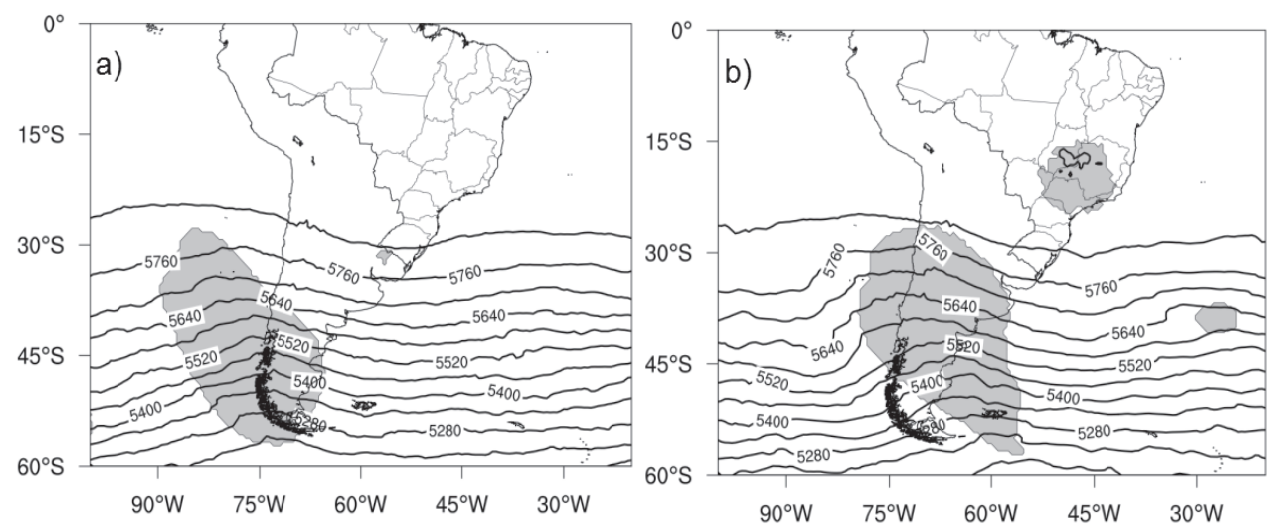

Figure 10 - As Figure 4, but to 500-hPa geopotential height (mgp) referring to D-1 (a) and D0 (b) for spring
Summer: Composite fields for summer were smoother than those for other seasons, especially 500-hPa geopotential height. Although composites of sea level pressure were not significantly different and northerly flow less intense when compared with other seasons, they are presented in Figure 13, since configuration showed in these fields helped modulate conditions for rainfall. For $\mathrm{K}$ index, it can be seen again, RS covered by values indicative of atmospheric instability, but only a small area shows differences between extreme and ordinary events (Fig. 14).

\section{Relation Between Extreme Rainfall and Instability Indices}

The mean characteristics of atmosphere shown above present how atmosphere organizes itself to produce an extreme rainfall event. It could be seen some indication of instability by instability 

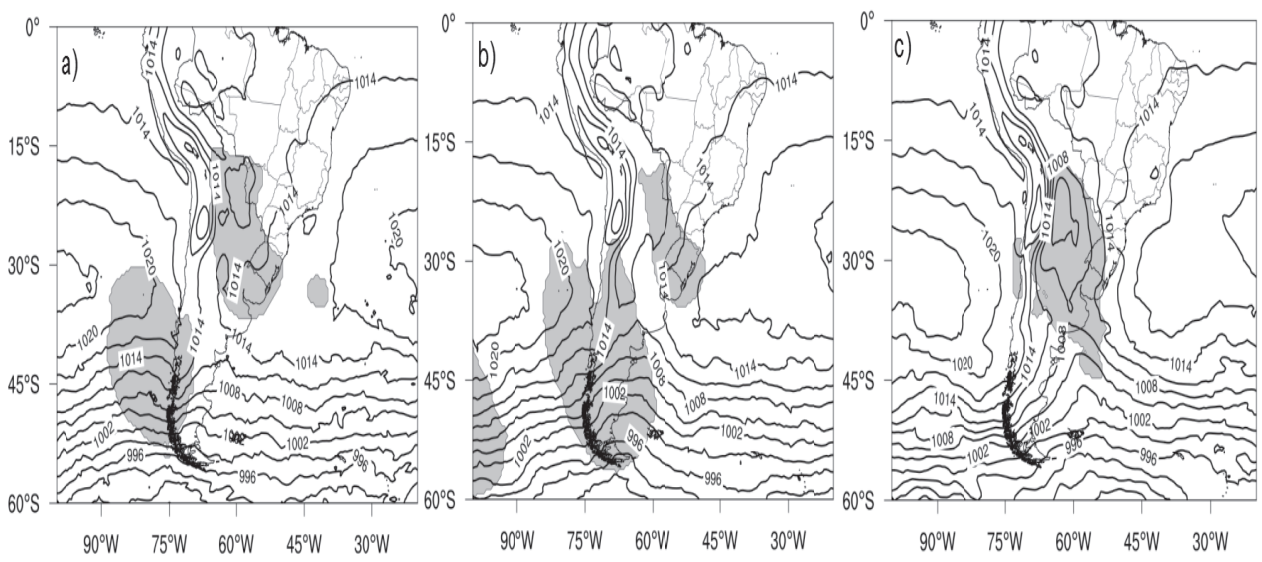

Figure 11 - As Figure 4, but to SLP (hPa) referring to D-2 (a), D-1(b) and D0 (c), respectively, for spring
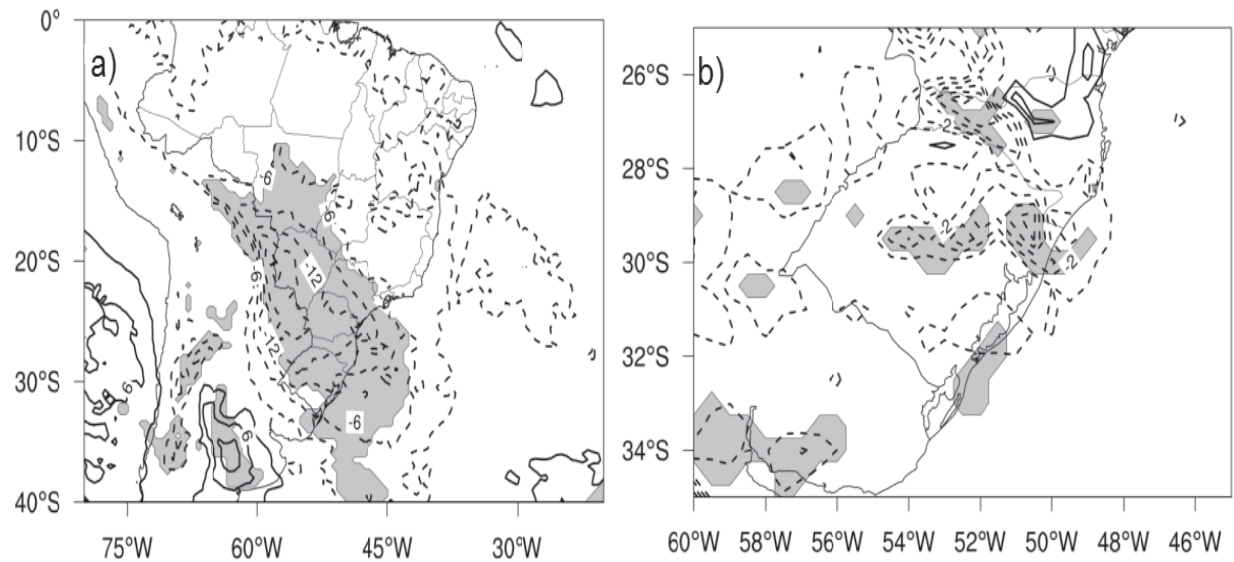

Figure 12 - As Figure 4, but to meridional wind ( $\mathrm{m} / \mathrm{s})$ at $850 \mathrm{hPa}$ (a) and moisture flux divergence $\left(10^{-7} \mathrm{~s}^{-1}\right)(\mathrm{b})$, referring to $\mathrm{D0}$ for spring.
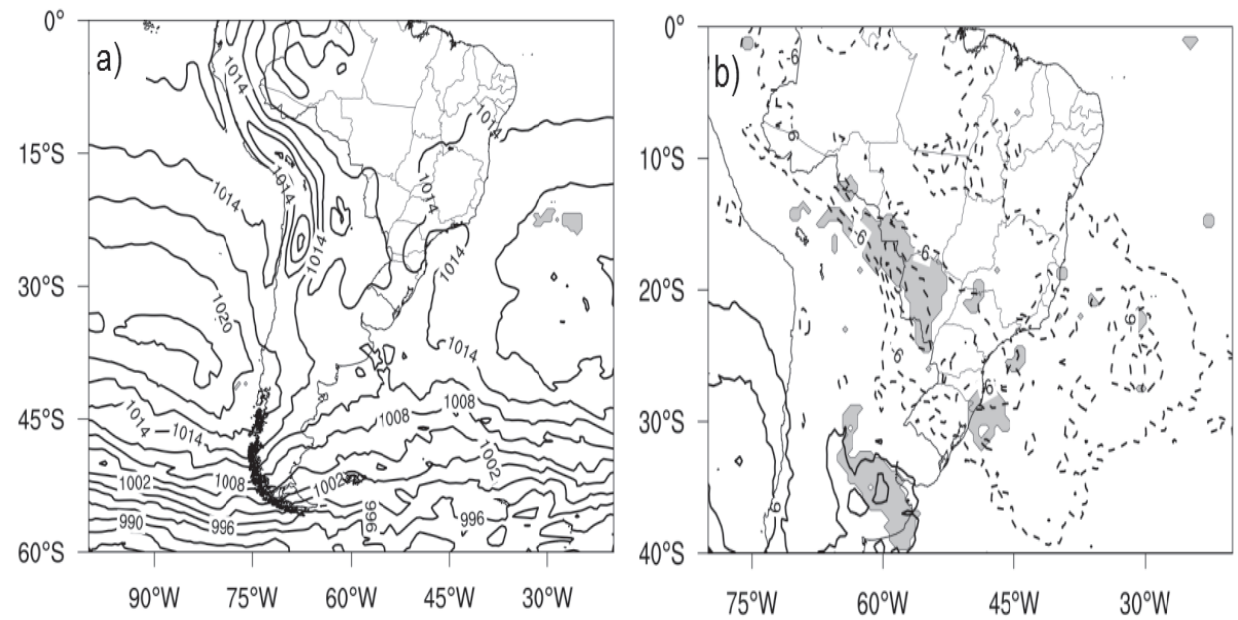

Figure 13 - As Figure 4, but to SLP (hPa) (a) and meridional wind (m/s) at $850 \mathrm{hPa}(\mathrm{b})$, referring to $\mathrm{D} 0$ for summer. 


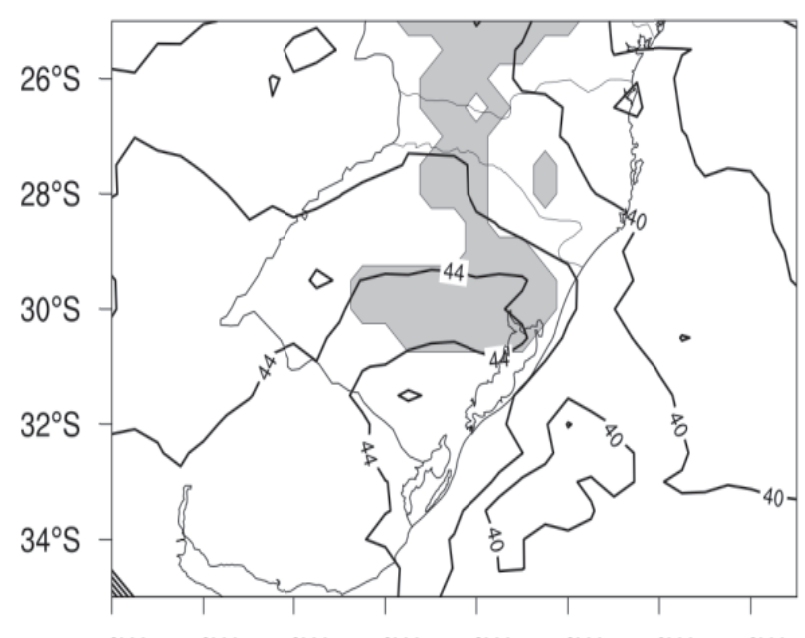

$60^{\circ} \mathrm{W} \quad 58^{\circ} \mathrm{W} \quad 56^{\circ} \mathrm{W} \quad 54^{\circ} \mathrm{W} \quad 52^{\circ} \mathrm{W} \quad 50^{\circ} \mathrm{W} \quad 48^{\circ} \mathrm{W} \quad 46^{\circ} \mathrm{W}$

Figure 14 - As Figure 4 , but to $K$ index $\left({ }^{\circ} \mathrm{C}\right)$, referring to $\mathrm{DO}$ for summer.

Table 3 - Summary of correlations between instability indices and cases of extreme rain.

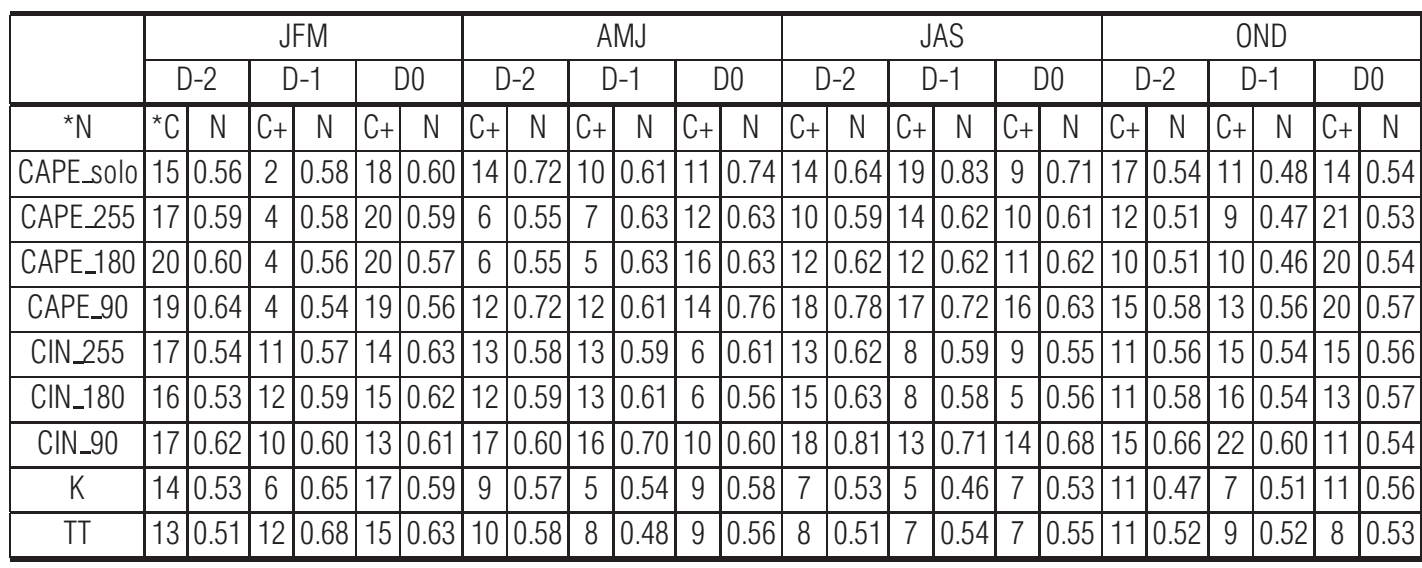

${ }^{*} \mathrm{~N}$ - Number of weather stations with significant correlation in the state-RS.

${ }^{*} \mathrm{C}+-$ Greater value significant correlation observed in state-RS.

indices. But, are instability indices a good indicator for extreme rainfall? To address this question correlation between extreme rainfall and instability indices was analyzed. Only most significant correlations (see Table 3), for each season are shown.

Autumn: Figure 15 and 16 show Spearman correlations for CAPE_ground, CAPE_90 and CIN_90, respectively, which present more significant correlation with extreme rainfall in autumn. For CAPE_ground, two days prior rainfall almost entire RS area has statistically significant correlations, being on average above 0.50 . From D-2 to D0 a decrease in the number of weather stations with significant correlation is observed, so the mean correlation over RS (Table 2). CAPE_90 and CIN_90 have similar spatial coverage of significant correlation, as well as almost same mean correlation over RS. CAPE_255 and CAPE_180 displayed more important correlations only on DO (not shown). For $K$ and TT indices only 9 weather stations were significant between D-2 to D0 (not shown).

Winter: Again, CAPE_ground and CAPE_90 present a large number of weather stations with significant correlation, showing correlations higher than 0.80 and 0.75 , respectively, slightly higher than observed in autumn (Fig. 17). Also, spatial coverage of significant correlation maintained almost fixed from D-2 to D0 (Table 3).

CAPE obtained from other start levels (CAPE_255 and CAPE_180; not shown) also presents significant correlation with 

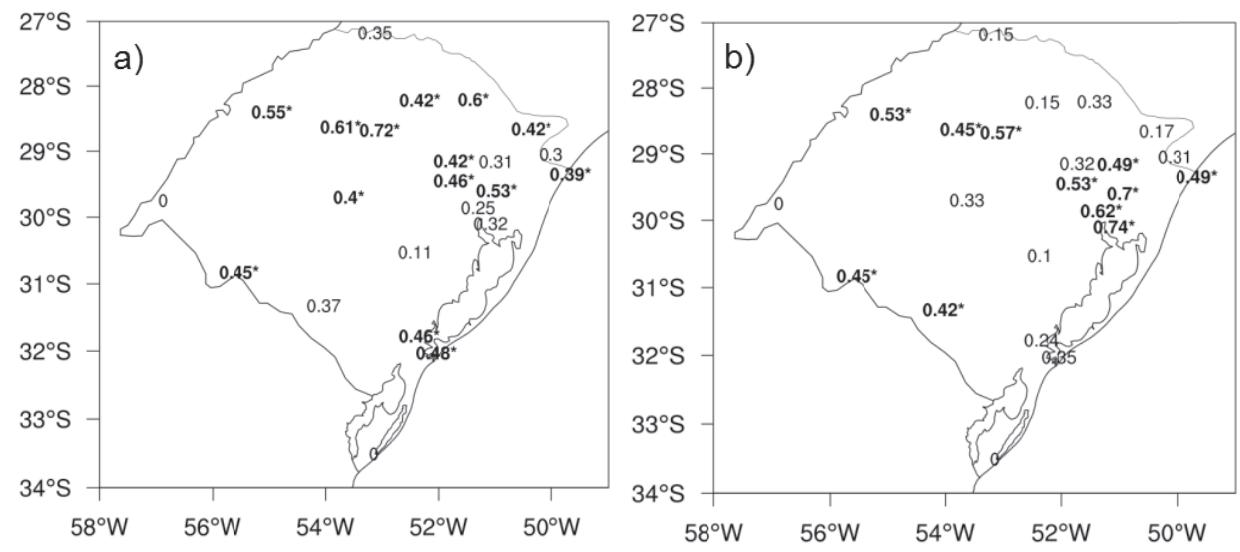

Figure 15 - Rank correlation coefficient between CAPE_ground and extreme rainfall on D-2 (a) and D0 (b). The fields are dimensionless, and values in bold marked with an asterisk show significant correlation.
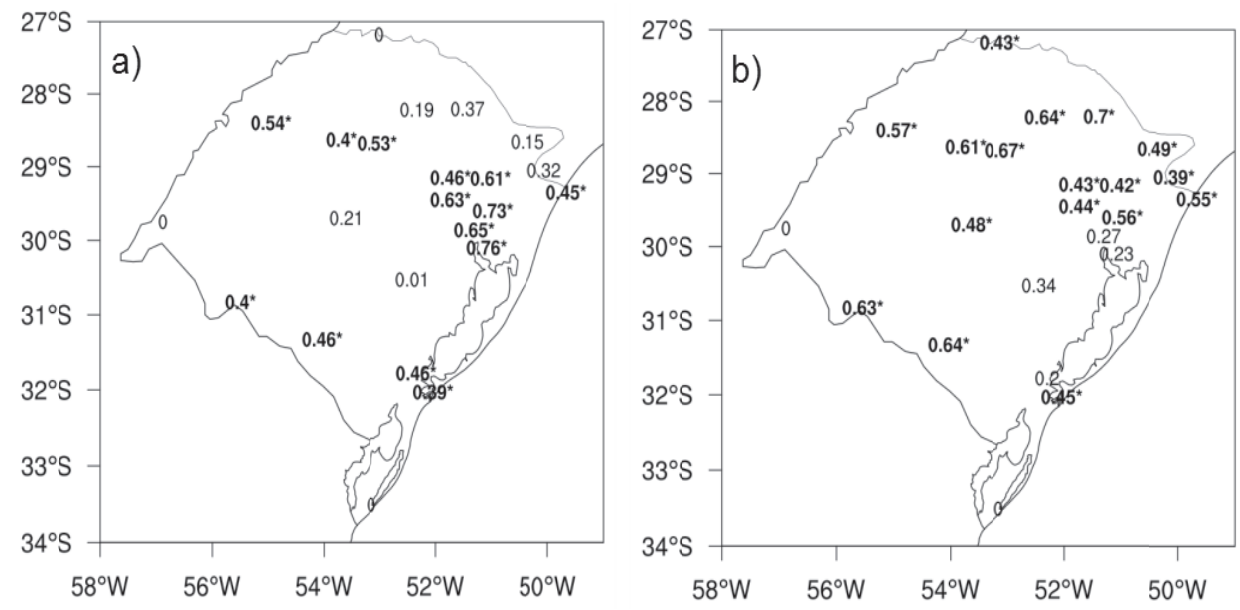

Figure 16 - As Figure 15, but to CAPE_90 on D0 (a) and CIN_90 on D-1 (b).
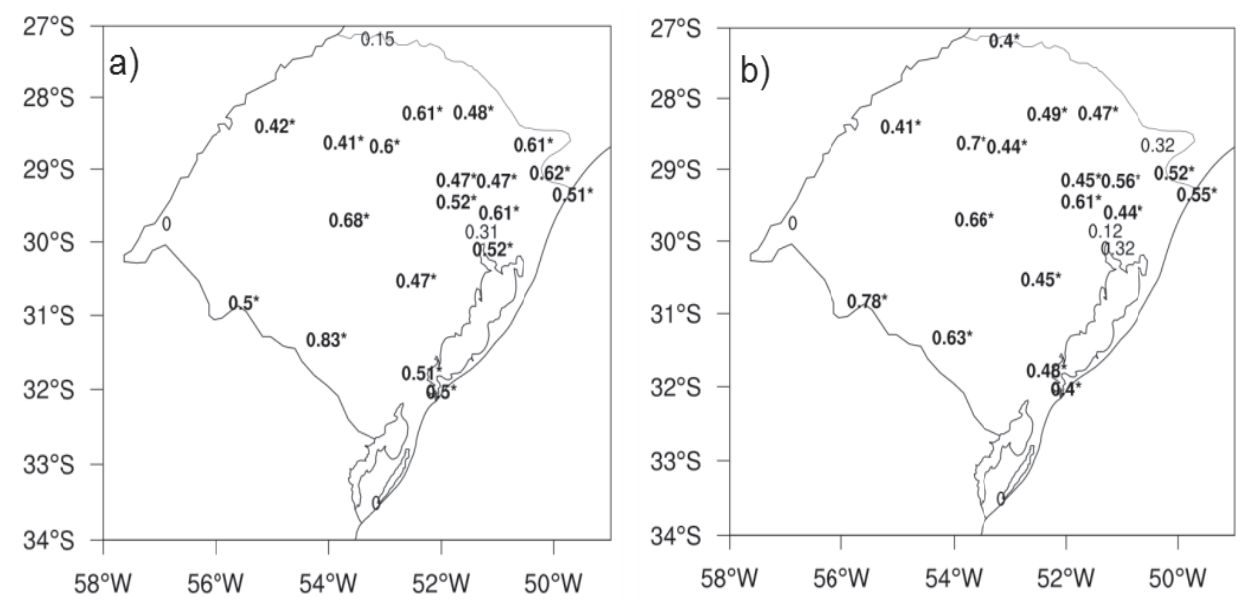

Figure 17 - As Figure 15, but to CAPE_ground (a) and CAPE_90 (b) on D-1 for winter. 
extreme rainfall, with maximum value of 0.62 and 13 weather stations with significant correlation. CIN_90 presents high correlations (above 0.7) two days prior extreme rainfall (Fig. 18). $\mathrm{K}$ and $\mathrm{TT}$ indices (not shown) had significant correlations, but with relatively small values as compared with autumn.

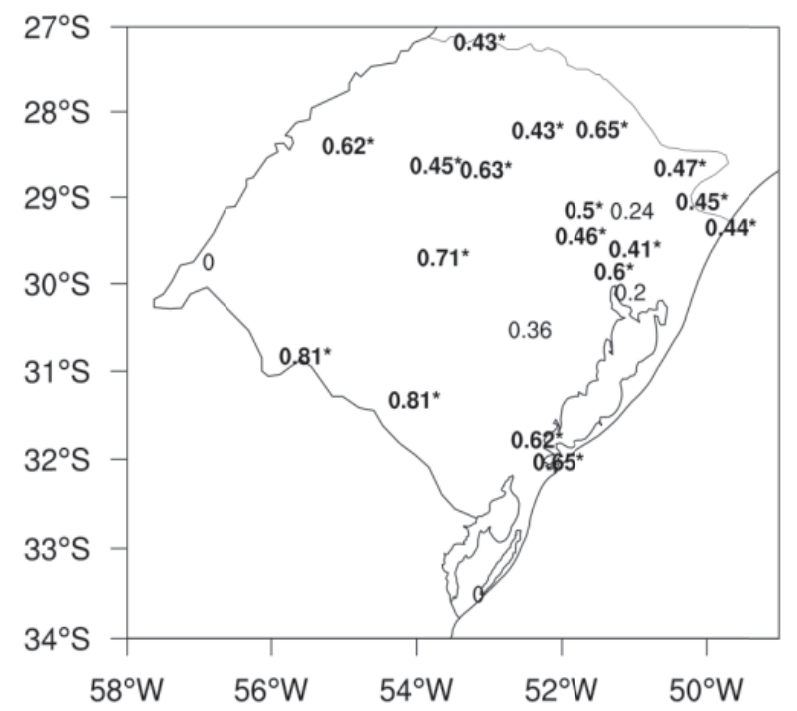

Figure 18 - As Figure 15, but to CIN_90 on D-2 for winter.

Spring: Correlations for CAPE at all starting levels had broader spatial coverage of significant correlation than autumn and winter seasons. CAPE_255, for example, has only 2 weather stations with non-significant correlations with rainfall (Fig. 19a). CIN_90 presents high spatial coverage of significant correlation and a maximum of 0.7 a day prior to extreme event (Fig. 19b). A decrease in the number of weather stations with significant correlation is observed for CIN_90 and CIN_255 (Table 3). K and TT indices, had about 10 weather stations significantly correlated (not shown). Even though amount of significant weather stations was larger than observed in autumn and winter, maximum values were not higher.

Summer: CAPE indices were similar to those observed in spring (Table 3). CAPE_ground and CAPE_255 were more significant a day prior extreme rainfall, with almost all weather stations having significant correlations, to CAPE_180 and CAPE_90 were more important on D-2 (not shown). CIN_255 presents significant correlations with larger spatial coverage than autumn on D-0, showing similarities with spring season (Fig. 20). Correlations between $\mathrm{K}$ and $\mathrm{TT}$ indices with extreme rainfall were more significant than in other seasons (Fig. 21), with $\mathrm{K}$ showing a huge increase in the number of weather stations with significant correlations: 6 on D-1 to 17 on D0. TT index does not show large variations in number of significant weather stations between days prior to rainfall and DO.

\section{DISCUSSION}

In this investigation, very low values for CAPE, compared with thresholds for strong convection, were observed in all seasons. These results can indicate that extreme rainfall events did not have strong relationship with CAPE. However, it is important to remember that composite fields are related to variables averaging and also they refer to 12 UTC, which is 9 local time. All of it can contribute to attenuated CAPE values here observed. Tavares \& Mota (2012) also found smaller values of CAPE when dynamic forcing was more intense, as compared with cases in which rainfall events depended on thermodynamic forcing for convective development. Some studies pointed the importance of dynamic forcing for break instability conditions (presence of high values of CIN), what favors occurrence of convection (Foss, 2011; Hallak, 2012). In addition, some studies found high values of CAPE before precipitation and a decreasing during or after its occurrence (Tavares $(2009,2010)$; Tavares \& Mota, 2012). In this study, increase of CAPE occurs from $D-1$ to $D 0$, corresponding to the beginning of daily rainfall accumulation (daily rainfall is recorded from 12 UTC of one day to 12 UTC of following day, being assigned as rainfall of the later). It is expected to observe a decrease of indices values if composites were extended up to a day after extreme event, as discussed by Tavares (2009). This author argues that this decrease occurs because cold air descending from cloud base, accompanying rainfall, contribute to diminish the temperature between cloud base and surface, leaving this part of atmosphere more stable.

The results of this study emphasize a discussion related to instability indices for Brazil, especially when they are used for rainfall forecasting. As shown above, lower values of CAPE are associated with extreme rainfall occurrence, what is highly linked to severe convection. Maybe, lower values of CAPE, as compared with thresholds shown in Table 3, may be sufficient for occurrence of severe convection, as discussed by Nascimento (2005). It is important to emphasize that instability indices are diagnostic tools for thermodynamic instability of atmosphere, but not for rainfall. Correlations between instability indices and extreme rainfall showed statistically significant linear relationship. It was also observed that some indices such as CAPE, for example, when calculated from a level above ground, have higher relationship with observed rainfall. This result is important, since may help meteorologists in correctly identify a potential environment for severe convection and, consequently, for extreme rainfall. It is common in weather forecasting centers the use of 

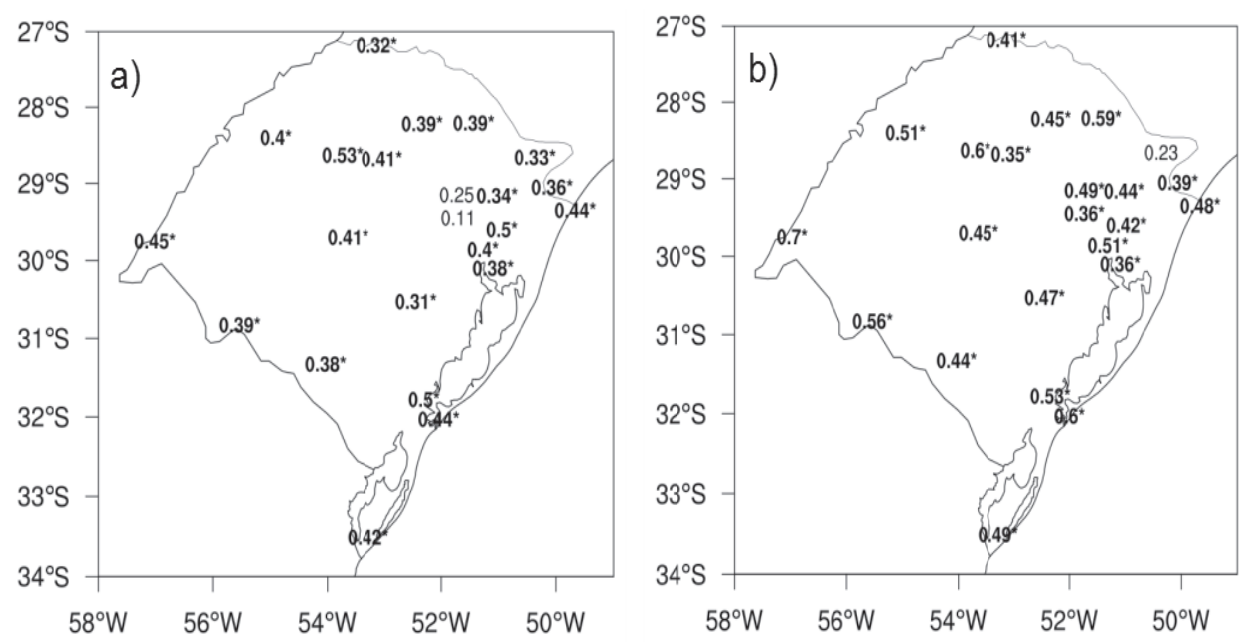

Figure 19 - As Figure 15, but to CAPE_255 on D-0 (a) and CIN_90 on D-1 (b) for spring.

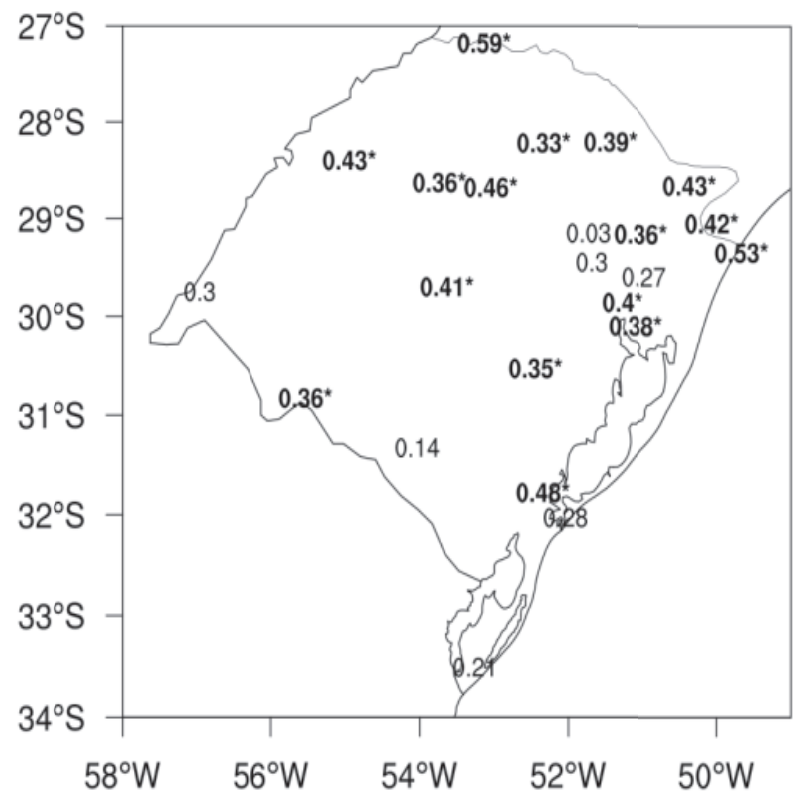

Figure 20 - As Figure 15, but to CIN_255 referring to D0 for summer.

instability indices calculated only from ground level, where not always is the level of higher instability. However, except for a few observations, the great majority of correlations for all seasons had values between 0.4 and 0.5 . The variability of a variable represented by another variable is, in this study therefore, between 16 and 25\%, approximately. It is shown, quantitatively, what it is empirically observed daily in forecasting centers about the task of predicting rainfall with instability indices. On the other words, the degree of convective instability of atmosphere has a very low correlation, although statistically significant, with the amount of rainfall observed. Thus, although results in Table 3 are an attempt to associate the magnitude of instability indices to rainfall amount, they have a very small contribution to quantitative rainfall forecasting. As mentioned above, there are situations in which convective potential is below the thresholds presented in Table 3, but large amount of rainfall is still observed. The methodology here used may impacted the results, but they agree with empirical knowledge of forecasters. However, it is not a suggestion to exclude instability indices from operational routines, but emphasizes that they should be used for what they were 

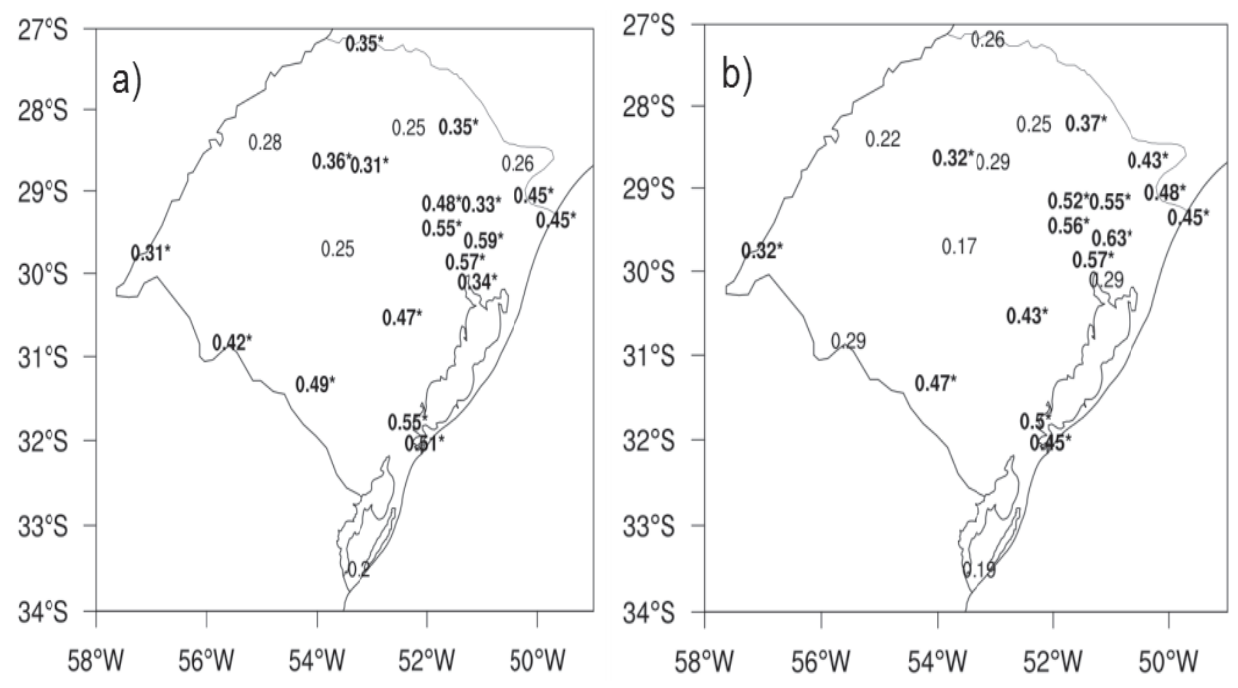

Figure 21 - As Figure 15 , but to $\mathrm{K}(\mathrm{a})$ and $\mathrm{TT}(\mathrm{b})$ indices $\left({ }^{\circ} \mathrm{C}\right)$, referring to $\mathrm{DO}$ for summer.

created: to describe the convective potential of atmosphere. The quantitative rainfall forecasting should use these and other tools, since many factors may contribute to rainfall occurrence and intensity. Also, it should be noted that there are no "magic numbers" to forecast these events, as discussed in Nascimento (2005) and Doswell \& Schultz (2006). This is a task of meteorologists to use available information and their experience for a better understanding of atmosphere behavior and for a better weather forecasting.

\section{CONCLUSION}

The purpose of this study is to evaluate the relationship between instability indices and extreme rainfall occurred in RS, Brazil. In addition, the search for forerunning synoptic-scale features associated with these extreme rainfall events. Based in composites for up to 2 days before extreme rainfall events, it could be observed how different they are comparing to ordinary rainfall events. Some common features observed in all season were: (i) formation of a surface thermal low pressure center in northern Argentina and Paraguay, (ii) intensification of northerly winds over Bolivia, Paraguay and northern Argentina, responsible for warm and moist air transportation for southern Brazil. This more intense northerly flow is associated with an increase of pressure gradient over the regions cited in (i). It was also observed (iii) moisture flux convergence over eastern Paraguay, northern Argentina and southern Brazil, especially over RS.

Correlations between instability indices and extreme rainfall showed statistically significant linear relationship for almost all indices. However, they did not show anticipated indication of rainfall occurrence, and also confirm what is empirically known: instability indices are bad tools to forecast rainfall. Quantitative rainfall forecasting should be performed by meteorologists using a set of tools and information. Instability indices can help meteorologists to identify atmospheric environments favorable to extreme convection, but they say nothing about amount of rainfall that can be observed in a forthcoming event.

\section{REFERENCES}

BLUESTEIN HB. 1993. Synoptic dynamic meteorology in midlatitudes: observations and theory of weather systems. New York: Oxford University Press, $594 \mathrm{pp}$.

CAVALCANTIIFA. 2012. Large Scale and Synoptic Features Associated with Extreme Precipitation over South America: A Review and Case Studies for the First Decade of the 21st Century. Atmos. Res., 118: 27-40, doi:10.1016/j.atmosres.2012.06.012.

DOSWELL CA III \& SCHULTZ DM. 2006. On the use of indices and parameters in forecasting severe storms. EJSSM, 1(3): 1-22.

FOSS M. 2011. Condições atmosféricas conducentes à ocorrência de tempestades convectiva severas na América do Sul. Master Dissertation on Meteorology, Programa de Pós-Graduação em Meteorologia, Universidade Federal de Santa Maria, Brazil, 2011. 145 pp.

GRIMM AM. 2009. Clima da região sul do Brasil. In: CAVALCANTIIFA, FERREIRA NJ, SILVA MGAJ \& DIAS MAFS (Org.). Tempo e Clima no Brasil. São Paulo: Oficina de Textos, p. 259-275.

HALLAK R. 2012. CAPE e CINE - Apostila Meteorologia Física I. Available on: <http://www.dca.iag.usp.br/www/material/>. Access on: Jan. 27, 2015. 
HENRY W. 1987. The Skew-T, Log P Diagram. National Weather Service Training Center, USA, 68 pp.

HOUZE RA. 2014. Cloud Dynamics. 2nd ed., Academic Press/Elsevier, $496 \mathrm{pp}$.

MARENGO JA, AMBRIZZI T \& SOARES WR. 2009. Jato de baixos níveis ao longo dos Andes. In: CAVALCANTI IFA, FERREIRA NJ, SILVA MGAJ \& DIAS MAFS (Org.). Tempo e Clima no Brasil. São Paulo: Oficina de Textos, p. 169-180.

NASCIMENTO EL. 2005. Previsão de tempestades severas utilizando-se parâmetros convectivos e modelos de mesoescala: uma estratégia operacional adotável no Brasil? Rev. Bras. Meteorol., 20: 121-140.

RAO VB \& HADA K. 1990. Characteristics of rainfall over Brazil: annual variations and connections with southern oscillation. Theor. Appl. Climatol., 42: 81-91.

RASMUSSEN KL \& HOUZE RA. 2016. Convective Initiation near the Andes in Subtropical South America. Mon. Wea. Rev., 144: 2351-2374, doi: 10.1175/MWR-D-15-0058.1.

RASMUSSEN KL, ZULUAGA MD \& HOUZE RA. 2014. Severe Convection and Lightning in Subtropical South America. Geophys. Res. Lett., 41: 7359-7366, doi:10.1002/2014GL061767.

REBOITA MS, KRUSCHE N, AMBRIZZI T \& ROCHA RP. 2012. Entendendo o tempo e o clima na América do Sul. Terrae Didat., 8(1): 34-50.

SAHA S, MOORTHI S, PAN HL, WU X, WANG J, NADIGA S, TRIPP P, KISTLER R, WOOLLEN J, BEHRINGER D, HAIXIA L, STOKES D, GRUMBINE R, GAYNO G, WANG J, HOU YT, CHUANG H, JUANG HMH, SELA J, IREDELL M, TREADON R, KLEIST D, DELST PV, KEYSER D, DERBER J, MICHAEL E, MENG J, WEI H, YANG R, LORD S, DOOL H, KUMAR A, WANG W, LONG C, CHELLIAH M, XUE Y, HUANG B, SCHEMM JK, EBISUZAKIW, LIN R, XIE P, CHEN M, ZHOU S, HIGGINS W, ZOU CZ, LIU Q, CHEN Y, HAN Y, CUCURULL L, REYNOLDS W, RUTLEDGE G \& GOLD-
BERG M. 2010. The NCEP Climate Forecast System Reanalysis. Bull. Amer. Meteor. Soc., 91: 1015-1057, doi:10.1175/2010BAMS3001.1.

SALIO P, NICOLINI M \& ZIPSER EJ. 2007. Mesoscale convective systems over southeastern South America and their relationship with the South American low-level jet. Mon. Wea. Rev., 135: 1290-1309.

TAVARES JPN. 2009. Tempestades severas na região metropolitana de Belém: avaliação das condições termodinâmicas e impactos sócioeconômicos. Master Dissertation on Environmental Sciences, Programa de Pós-graduação em Ciências Ambientais, Universidade Federal do Pará/EMBRAPA/Museu Emilio Goeldi, Belém, Brazil, 2009. 101 pp.

TAVARES JPN \& MOTA MAS. 2012. Condição termodinâmica de eventos de precipitação extrema em Belém-PA durante a estação chuvosa. Rev. Bras. Meteorol., 27: 207-218.

TEDESCHI RG, GRIMM AM \& CAVALCANTI IFA. 2014. Influence of Central and East ENSO on extreme events of precipitation in South America during austral spring and summer. Int. J. Climatol., doi:10.1002/joc.4106

TEIXEIRA MS. 2010. Caracterização física e dinâmica de episódios de chuvas intensas nas regiões sul e sudeste do Brasil. PhD Thesis on Meteorology, Programa de Pós-graduação em Meteorologia, Instituto Nacional de Pesquisas Espaciais, São José dos Campos, Brazil, 2010. $190 \mathrm{pp}$.

VELASCOI \& FRITSCH JM. 1987. Mesoescale convective complexes in the Americas. J. Geophys. Res., 92: 9591-9613.

WILKS DS. 2006. Statistical Methods in the Atmospheric Sciences. 2nd ed., International Geophysics Series, vol. 91, Academic Press, $627 \mathrm{pp}$.

ZIPSER EJ, CECIL DJ, LIU C, NESBITT SW \& YORTY DP. 2006. Where are the Most Intense Thunderstorms on Earth? Bull. Amer. Meteor. Soc., 87: 1057-1071, doi:10.1175/BAMS-87-8-1. 